\title{
IMPROVEMENT OF EXPANSIVE SUBGRADE BY LIME ADDITION
}

\author{
Afaf A H M. ${ }^{1}$, Hesham A. H. I. ${ }^{2}$, Atef A.Elh. M. ${ }^{3}$ \\ ${ }^{1,3}$ Staff in Civil Eng. Dep., Faculty of Eng., Minia University \\ ${ }^{2}$ Lecture, Geology Dep., Faculty of Science, South Valley University
}

Received 14 July 2013; accepted 12 September 2013

\begin{abstract}
Qena - Safaga road is considered to be one of the most important roads connecting southern Egypt governorates to the Red-Sea.The swelling action of the subgrade of this road ( between $\mathrm{Km}$ 18 to $\mathrm{Km} 32$ ) has led to many cracklings' of the pavements, building foundations and water lines. Sediments had been observed. This action led to a heave and cracking of pavements, building foundations, water lines.

This research deals with an investigation of the important properties of the road subgrade soil including plasticity, unconfined compressive strength and swelling pressure. The research also deals with the effect of hydrated lime addition and curing time on improving the important properties of such kind of subgrade, expansive marly clay. Using the optimum lime content of $6 \%$ by the same, the properties showed many satisfactory results. Plasticity and swelling pressure values decreased and unconfined compressive strength value increased. Also, the test results showed the strong effect of the curing time on enhancing this type of subgrade.

Keywords: Swelling Subgrade, Expansive soil, hydrated lime, microstructural analysis, unconfined strength, California bearing ratio.
\end{abstract}

\section{Introduction}

Soil that has the tendency to swell when their moisture content increases is called expansive soil. The moisture may caused by many reasons such as rain flooding, leaking water or the reduction in surface evaporation when an area in covered by a pavement. Problems associated with expansive soil are due to the swelling action of the subgrade which causes cracking and breakup of the pavements as has been observed along QenaSafaga road in Egypt (between $\mathrm{km} 18$ to $\mathrm{km}$ 32, from Qena to Safaga).The subgrade in this area consists of Pliocene marly sediments which severely suffered from deterioration origingating from swelling when being in contact with water in interval values. The volume changes in the studied samples are important because of their consequence in terms of settlement due to compression or heave due to expansion swelling. In addition, change in volume leads to change in strength and deformation properties that in turn influence stability. This phenomena was observed from the high values of the plasticity index as shown by Badry (2004). In the investigated zone of Qena-Safaga road, the expansive subgrade of that road has been swelled due to water coming from the damage of old water pipes which led to a heave of the road. In addition, drying the saturated sedimentary facieses due to sun rays led to a formation of large scale mud cracks having polygonal forms and other cracks with random orientations. These cracks occur on the asphalt layer and in the area around the road. Ggrouting of the cracks using cement and chemical stabilization of that expansive subgrade sedimentary faciesesbusing lime are suggested in order to reduce the swelling.

Corresponding author.

Email address: af_mahmoud@yahoo.com 


\section{Lime Stabilization}

One method of controlling volume changes is to stabilize expansive clay soils with admixtures that prevent volume changes or adequately modify the volume change characteristics of an expansive clay soils, (Kehew, 1995).

The use of lime for stabilization plastic montmorillonitic clays has been increased in favor during the last few decades because it lowers volume change characteristics TRB (1976). Addition of lime to clay soil provides an abundance of calcium ions $\left(\mathrm{Ca}^{2+}\right)$ and magnesium ions $\left(\mathrm{Mg}^{2+}\right)$. These ions tend to displace other common actions such as sodium $\left(\mathrm{Na}^{+}\right)$or potassium $\left(\mathrm{K}^{+}\right)$, in a process known as action exchange replacement of sodium or potassium ions with calcium significantly reduces the plasticity index of the clay. A reduction in plasticity is usually accompanied by reduced potential for swelling. The addition of lime increases the soil $\mathrm{pH}$, which also increases the action exchange capacity.

A change of soil texture takes place when lime is mixed with clays. As the amount of lime is increased, there is an apparent reduction in clay content and a corresponding increase in the percentage of coarse particles, (Chen 1975). He generally, found that the amount of lime required to stabilize expansive soils ranges from 2-8 \% by weight. Addition of sufficient amount of lime to expansive mudstone to produce a $P H$ of 12.4 or equal to a $P H$-value of lime itself. A graph is plotted between $p H$-value versus lime percentage. Optimum lime content should be determined corresponding to maximum $\mathrm{pH}$ value of lime-mudstone mixture. In the present study, an optimum lime content to treat the crushed expansive mudstone is taken 6\% Fig. (1). Badry (2012) used hydrated lime to improve the geotechnical properties and to treat the swelling problem of the expansive soils in the subgrade of the upper Egypt Red Sea Roada. He suggested an optimum lime content of 5\% . Also, in South Africa, Okonta \& Menciya (2010) used lime and fly ash to stabilize Berea Ring sand. Their results showed a significant improvement on the strength and bearing properties. The evaluation of the adequacy of using Egyption limestone deposits for the use in highway pavements was conducted by Mahrous et al (2010). The results showed that Aswan, Qena and Minia samples contain limestones with high uniaxial and tensile strength.

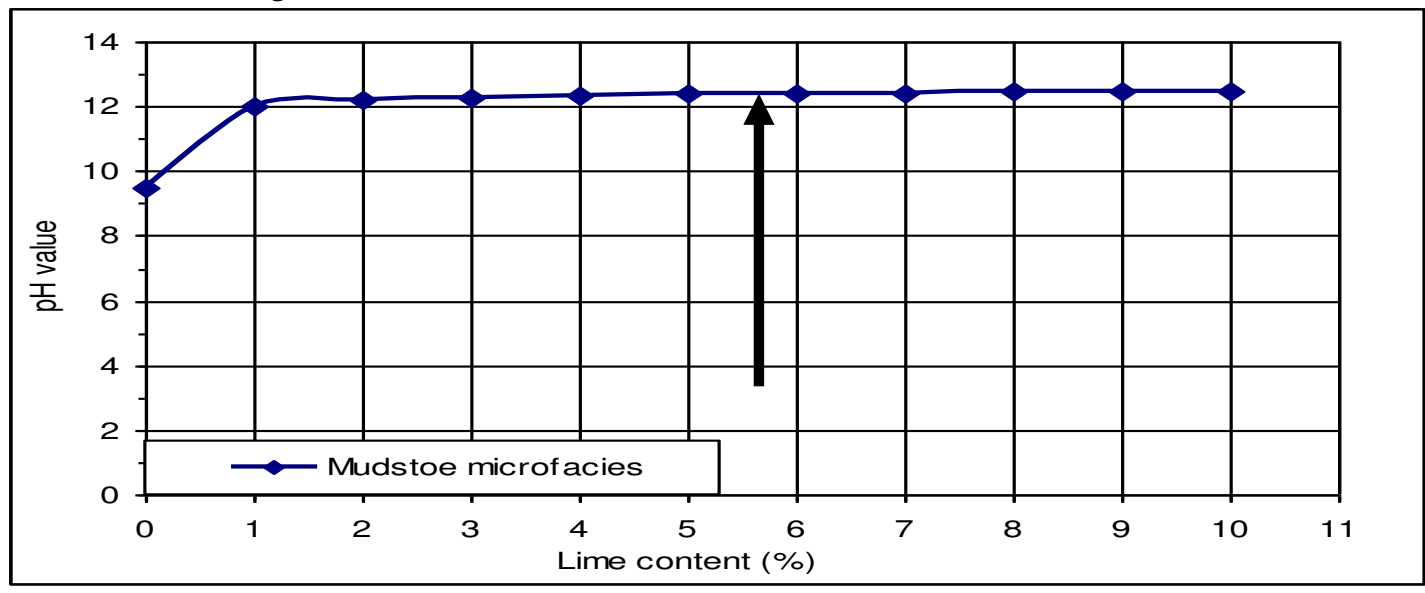

Fig. 1. Relationship between $p H$-values and Lime content $(\%)$ to determine the optimum lime content of an expansive mudstone.

Journal of Engineering Sciences, Assiut University, Faculty of Engineering, Vol. 41, No. 5, September, 2013,E-mail address: jes@aun.edu.eg 


\section{Treatment Methodology}

In the present study, the suggested treatment of the expansive Pliocene subgrade (expansive mudstone microfacies ) using chemical stabilization to reduce the swelling pressure and avoid the heave which leads to the formation of the cracks is presented at the mentioned area. Several parameters ( including plasticity, compaction, swelling pressure, California bearing ratio and unconfined compressive strength) were measured for both untreated mudstone and treated ones in order to evaluate the lime chemical stabilization process.

\section{Experimental Work}

The experimental work proposed in this research is directed to investigate the effect of adding lime and curing period on swelling potential of Pliocene subgrade Atterberge limits, unconfined compressive strength, and SEM-analysis (Microstructural analysis) in case of studied sample (mudstone). Studied soil composed of Calcite, Illite, and Dolmite. Studied sample and lime are crushed and sieved to pass through a No, 40. All of material were heated and dried for $24 \mathrm{~h}$ at $50^{\circ} \mathrm{C}$. Samples were prepared by mixing a calculated amount of stabilizer with studied sample to obtain a sample with a predetermined percentage of stabilizers which reach to $6 \%$ from studied sample. Chemical composition of studied sample and lime. Chemical analysis of studied sample and lime are presented in Table [1,2].

\section{Table 1.}

Chemical analysis of mudstone.

\begin{tabular}{|c|c|c|c|c|c|c|c|c|c|c|c|c|}
\hline $\begin{array}{l}\text { Chemica } \\
\text { I Oxides }\end{array}$ & $\mathrm{S}_{\mathrm{i}} \mathrm{O}_{2}$ & $\begin{array}{l}\mathrm{T}_{\mathrm{i}} \mathrm{O} \\
2 \\
\end{array}$ & $\begin{array}{l}\mathrm{Al}_{2} \mathrm{O} \\
3\end{array}$ & $\begin{array}{l}\mathrm{Fe}_{2} \mathrm{O} \\
3\end{array}$ & $\begin{array}{l}\mathrm{Mn} \\
\mathrm{O}\end{array}$ & $\begin{array}{l}\mathrm{Mg} \\
\mathrm{O}\end{array}$ & $\mathrm{CaO}$ & $\begin{array}{l}\mathrm{Na}_{2} \\
\mathrm{O}\end{array}$ & $\begin{array}{l}\mathrm{K}_{2} \\
\mathrm{O}\end{array}$ & $\begin{array}{l}\mathrm{P}_{2} \mathrm{O} \\
5\end{array}$ & $\mathrm{SO}_{3}$ & $\begin{array}{l}\text { L.O. } \\
\text { I }\end{array}$ \\
\hline $\begin{array}{c}\text { Percent } \\
(\%)\end{array}$ & $\begin{array}{l}25.1 \\
4\end{array}$ & $\begin{array}{l}0.1 \\
3\end{array}$ & 4.22 & 1.06 & 0.01 & 6.72 & $\begin{array}{l}29.0 \\
5\end{array}$ & 1.10 & $\begin{array}{l}0.4 \\
0\end{array}$ & 0.33 & $\begin{array}{l}0.4 \\
4\end{array}$ & $\begin{array}{l}30.9 \\
6 \\
\end{array}$ \\
\hline
\end{tabular}

\section{Table .2.}

Chemical analysis of lime.

\begin{tabular}{|l|c|c|c|c|c|c|c|c|c|c|c|c|}
\hline Chemical Elements & $\mathrm{Mg}$ & $\mathrm{Al}$ & $\mathrm{Si}$ & $\mathrm{Cl}$ & $\mathrm{k}$ & $\mathrm{Ta}$ & $\mathrm{Ti}$ & $\mathrm{Mn}$ & $\mathrm{Fe}$ & $\mathrm{p}$ & $\mathrm{Na}$ & L.O.I \\
\hline Percent (\%) & 1.9 & 0.1 & 1.1 & ---- & 0.27 & 62.6 & 0.01 & ----- & 1.4 & 0.01 & 0.55 & 32 \\
\hline
\end{tabular}

\subsection{Plasticity test}

Casagrande is the apparatus which used in this test, where it consists of a brass dish, which hinged in the top of apparatus by cam, grooving tool, and spatula (ASTM-ref.10). This apparatus is used to determine the liquid limit of clayey samples. The results of these water content determinations are then plotted to a semi logarithmic scale against the corresponding number of blows. The points thus obtained usually fall along a straight line. Soil-lime mixture (6 \%lime) were determined after 7 and 28 days curing according to DIN 18 122-1 and TPBF-StB, part B11.5, 1991.

Journal of Engineering Sciences, Assiut University, Faculty of Engineering, Vol. 41, No. 5, September, 2013, E-mail address: jes@aun.edu.eg 


\subsection{Swelling test}

Oedometer instrument was used to investigate the volume change characteristics of studied sample (in case of nature and treated sample), where two specimens used for each test. The test specimen is in the form of a disc, held inside a metal ring and lying between two porous stone. The upper porous stone, which can move inside the ring with a small clearance, is fixed below a metal loading cap through which pressure can be applied to the specimen. The whole assembly sits in an open cell of water to which the pore water in the specimen has free access. The ring confining the specimen is floating (being to move vertically). The inside of the ring has a smooth polished surface to reduce side friction. The compression or swell of the specimen under pressure is measured by the means of dial gauge operating on the load cap, Fig.(2).

A series of Oedometer tests on studied specimens were carried out to observe their swelling behavior. The relation between time and change in volume of every sample is recorded under different five stresses level, $(0.25 \mathrm{~kg} / \mathrm{cm} 2,0.5 \mathrm{~kg} / \mathrm{cm} 2,1 \mathrm{~kg} / \mathrm{cm} 2,2$ $\mathrm{kg} / \mathrm{cm} 2,4 \mathrm{~kg} / \mathrm{cm} 2$ and $8 \mathrm{~kg} / \mathrm{cm} 2$ ). The vertical deformation of the studied specimen was recorded at time intervals of $1,2,4,8,15,30$ minutes and 1, 2, 4, 8, 24 hours. Studied sample treated using mixing it with lime (6\% lime) and compacted. After compaction the specimens were extruded, sealed in polyethylene paper, and stored in $\geq 98 \%$ relative humidity at $40^{\circ} \mathrm{C} \pm 2$ for 7 and 28 days curing (for soil-lime mixtures) in computerized temperature-humidity chamber.

\subsection{Unconfined compressive strength test}

Unconfined compressive strength tests were conducted on the untreated and treated studied sample using CBR (24030 Brembate Sopra-Italy) instrument. The dimensions of the tested specimens are $10 \mathrm{~cm}$ hight and $5 \mathrm{~cm}$ diameter, two specimens used for each test. Unconfined compressive strength (qu-value) of the tested specimens is at the failure of the specimen Fig.(3).

Unconfined compressive strength tests were conducted on the treated mudstone sample with addition of $6 \%$ lime using CBR (24030 Brembate Sopra-Italy) instrument.

After compaction the specimens were extruded, sealed in polyethylene paper, and stored in $\geq 98 \%$ relative humidity at $40^{\circ} \mathrm{C} \pm 2$ for 7 and 28 days curing (for soil-lime mixtures) in computerized temperature-humidity chamber.

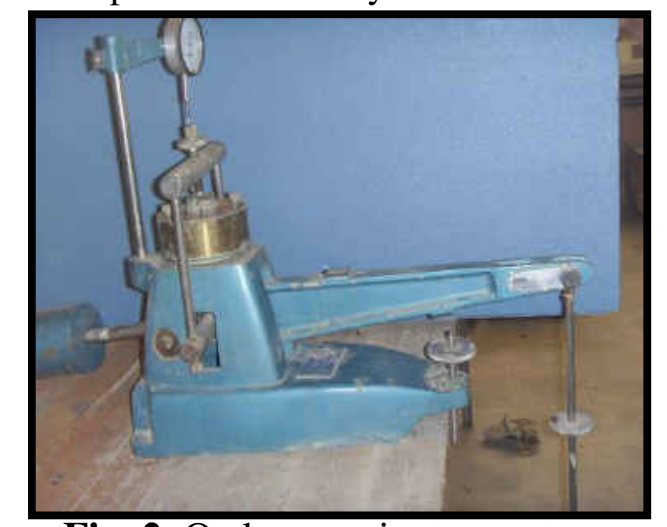

Fig. 2. Oedometer instrument.

Journal of Engineering Sciences, Assiut University, Faculty of Engineering, Vol. 41, No. 5, September, 2013,E-mail address: jes@aun.edu.eg 


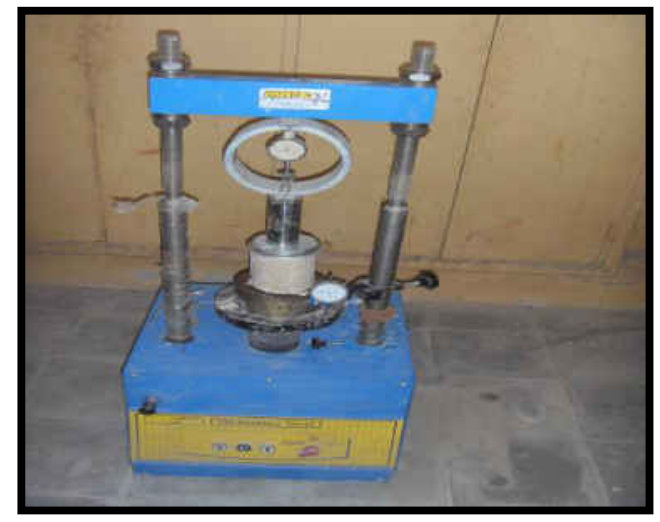

Fig. 3. Qu-instrumen

\subsection{California bearing ratio $(C B R)$ test}

California bearing ratio test (CBR-test) was conducted according to (TPBF-STB part B $7.1,1988)$ for untreated compacted mudstone with optimum water content and for treated stabilized mudstone with optimum water content using modified proctor effort and CBR mechanical instrument (HUMBOIDT-MFG.CO.H4454-USA). The dimensions of the tested specimen are $11.65 \mathrm{~cm}$ height $(\mathrm{H})$ and $15.2 \mathrm{~cm}$ diameter $(\varnothing)$. The test was conducted with annular surcharge mass of $5 \mathrm{~kg}$. The $C B R$ values are calculated by the following equation.

Where:

$$
C B R=P / P s^{*} 100
$$

$P$ is plunger-load in $\mathrm{kg} / \mathrm{cm}^{2}$ for tested soil, and

$P$ s is plunger-load in $\mathrm{kg} / \mathrm{cm}^{2}$ for standard soil

The general relationship between $C B R$-values and quality of sub-grade used in pavement applications (Bowles, 1992) is shown in Table [3].

\section{Table 3.}

Relationship between $C B R$-values and quality of sub-grade used in pavement applications (Bowles, 1992).

\begin{tabular}{|c|c|}
\hline CBR-values (\%) & Quality of sub-grade \\
\hline $0-3$ & very poor \\
\hline $3-7$ & poor to fair \\
\hline $7-20$ & fair \\
\hline $20-50$ & good \\
\hline$>50$ & excellent \\
\hline
\end{tabular}

Journal of Engineering Sciences, Assiut University, Faculty of Engineering, Vol. 41, No. 5, September, 2013, E-mail address: jes@aun.edu.eg 


\subsection{Slaking durability test}

This test is used to measure the slaking durability of the studied samples and their resistance for surround bad conditions. It was carried out according to Franklin and Chandra (1972). The apparatus consists of a drum $140 \mathrm{~mm}$ in diameter and $100 \mathrm{~mm}$ long with sieve mesh forming the cylindrical walls ( $2 \mathrm{~mm}$ opening). About $500 \mathrm{~g}$ of rock is broken into10lumps and put inside the drum which is turned at 20 revolutions per minute in a water bath Fig. (4). After 10- minutes of rotation, the percent of retained rock weight inside the drum, on a dry weight basis, was reported as the slake durability index (Id). Gamble (1971) proposed using a second 10-minutes cycle after drying. Values of the slake durability index for representative shales and claystones tested by Gamble varied over the whole range from 0 to $100 \%$. Based upon Gamble's results, a classification of slakes durability was proposed Table [4].

\section{Table 4.}

Gamble slake durability classification.

\begin{tabular}{|l|c|}
\hline \multicolumn{1}{|c|}{ Group Name } & $\begin{array}{c}\text { Retained \% after two10- } \\
\text { minute cycle (Dry } \\
\text { weight basis) }\end{array}$ \\
\hline Very high durability & $>98$ \\
\hline High durability & $95-98$ \\
\hline Medium high durability & $85-95$ \\
\hline Medium medium high & $60-85$ \\
\hline Low durability & $30-60$ \\
\hline Very low durability & $<30$ \\
\hline
\end{tabular}

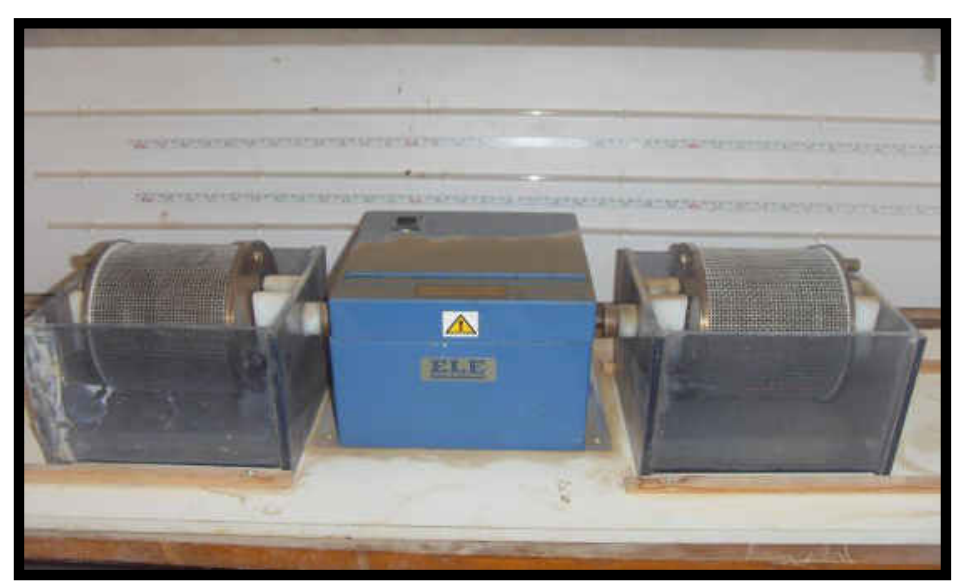

Fig. 4. Slaking durability instrument

\subsection{Compaction test}

The aim of the proctor test (compaction test) is to determine an optimum water content of both natural crushed and lime treated mudstone. Compaction curves corresponding to modified proctor effort are determined for nature and treated mudstone. Compaction curve Journal of Engineering Sciences, Assiut University, Faculty of Engineering, Vol. 41, No. 5, September, 2013, E-mail address: jes@aun.edu.eg 
Afaf A H M.et al., Treatment of Expansive Subgrade By Lime Addition, pp. 1778 - 1795

(DIN 18 127) for nature crushed mudstone is a typical bell-shape Fig. (5).The maximum dry density weight and the optimum water content are $1.67 \mathrm{~g} / \mathrm{cm}^{3}$ and $18.6 \%$ respectively. The curve is narrowing bell-shape. Compaction curve for treated mudstone is obtained Fig. (5). The maximum dry density and the optimum water content are $1.62 \mathrm{~g} / \mathrm{cm}^{3}$ and $19.4 \%$ respectively. The curve is flattened bell-shape.

Generally, the addition of lime to the studied crushed mudstone leads to increase the optimum water content and decrease the maximum dry density.

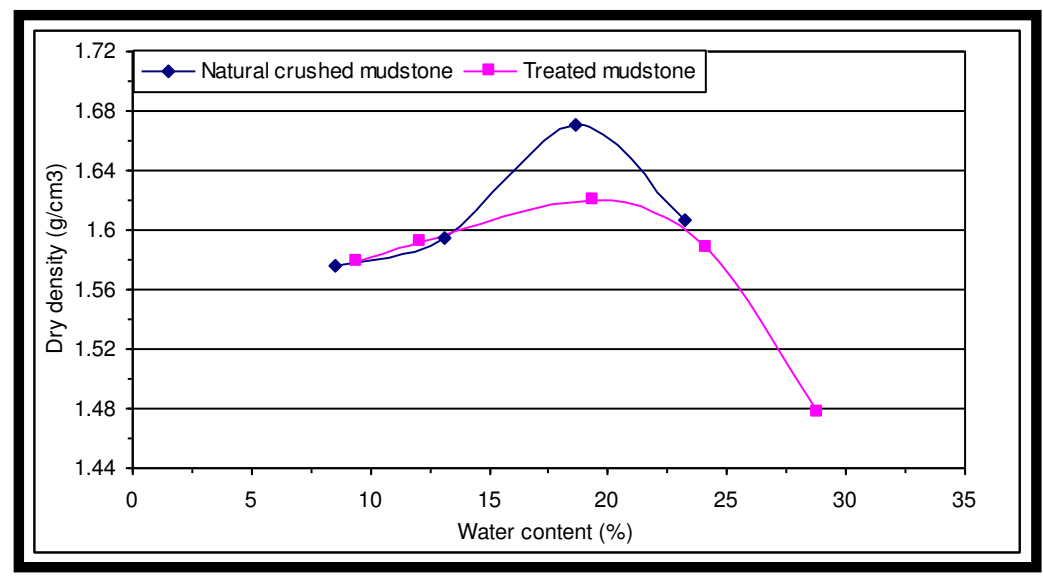

Fig. 5. Compaction curves of natural crushed and treated mudstone.

\section{Test Results and Analysis}

\subsection{Plasticity test results}

Effect of lime stabilization and curing period on plasticity index for untreated soil is shown in Fig. (6). Plasticity index for untreated and treated soil for 7 and 28 days were 9.91, 5.36, and 4.3 respectively. Adding lime to soil decrease the plasticity index for untreated soil by $56.61 \%$. The results clearly indicates the effect of curing time on reducing the P.I without change of the lime addition percentage.

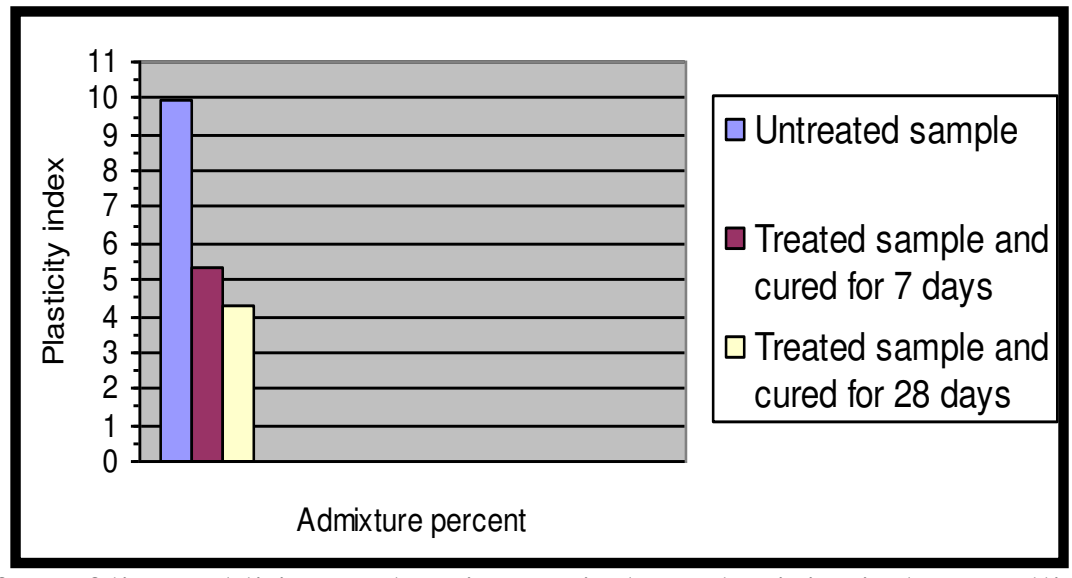

Fig. 6. Effect of lime addition and curing period on plasticity index swelling pressure

Journal of Engineering Sciences, Assiut University, Faculty of Engineering, Vol. 41, No. 5, September, 2013, E-mail address: jes@aun.edu.eg 


\subsection{Swelling pressure test results}

Swelling pressure of both natural and lime treated mudstone is measured using Oedometer test. The results are showed in Figs.(7,8,9to12).The vertical deformation of lime treated mudstone samples cured for 7 and 28 days is recorded along certain period of time under stress levels of $0.25,0.50,1,2,4$ and $8 \mathrm{~kg} / \mathrm{cm}^{2}$.

Fig. (9) shows the relation between the vertical displacements versus time for the treated mudstone cured for 7 days. The figure indicates that the previous relation is obtained under six stress levels $\left(0.25,0.50,1,2,4\right.$ and $\left.8 \mathrm{~kg} / \mathrm{cm}^{2}\right)$. It could be noticed that the zero time started from the moment of adding water to the loaded treated mudstone sample. The figure illustrates that the treated mudstone (7days curing) sample is heaved under stress level of $0.25 \mathrm{~kg} / \mathrm{cm}^{2}$ to $0.05 \%$. It began to compress (settlement) with increase of stresses values $\left(0.50,12,4\right.$ and $\left.8 \mathrm{~kg} / \mathrm{cm}^{2}\right)$ to $1.11 \%$. The rate of settlement increased by increase of time and stress levels. The difference of settlement values and their increase rate under effect of the stresses $\left(0.50,1,2,4\right.$ and $\left.8 \mathrm{~kg} / \mathrm{cm}^{2}\right)$ are relatively small.

Fig. (10) shows the change of the vertical displacement of the lime treated mudstone sample (7days curing) with stress levels recorded at the end of tested period of 24hours. It could be noticed from this figure that the heave of sample happened under effect of $0.25 \mathrm{~kg} / \mathrm{cm}^{2}$. The heave values are decreased with increasing of stress levels. The settlement of the studied sample happened under effect of stresses equal to $0.50,1,2,4$ and $8 \mathrm{~kg} / \mathrm{cm}^{2}$ ). The figure explained that the swelling pressure of this sample is $0.4 \mathrm{~kg} / \mathrm{cm}^{2}$.

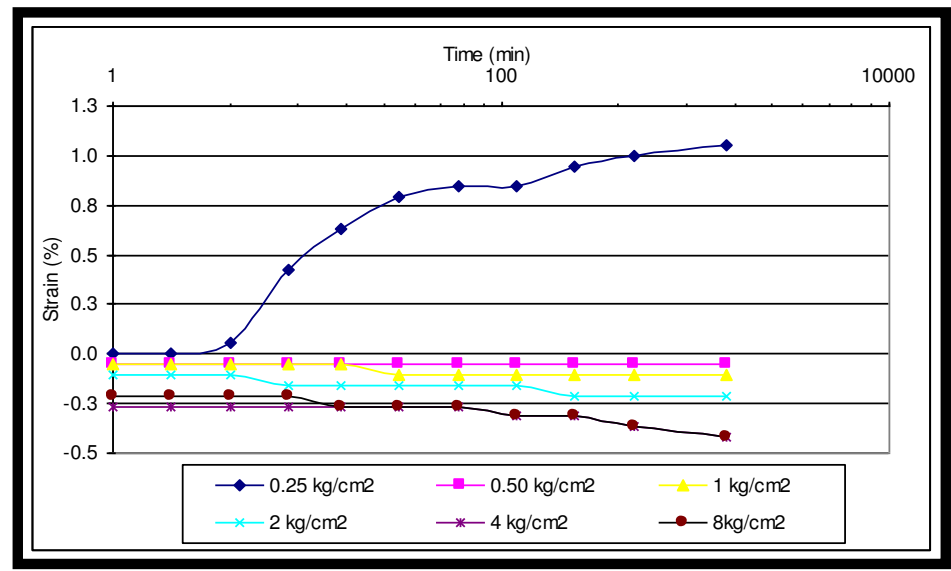

Fig.7.Vertical deformation versus time under different applied stress levels for mudstone microfiches

Journal of Engineering Sciences, Assiut University, Faculty of Engineering, Vol. 41, No. 5, September, 2013, E-mail address: jes@aun.edu.eg 


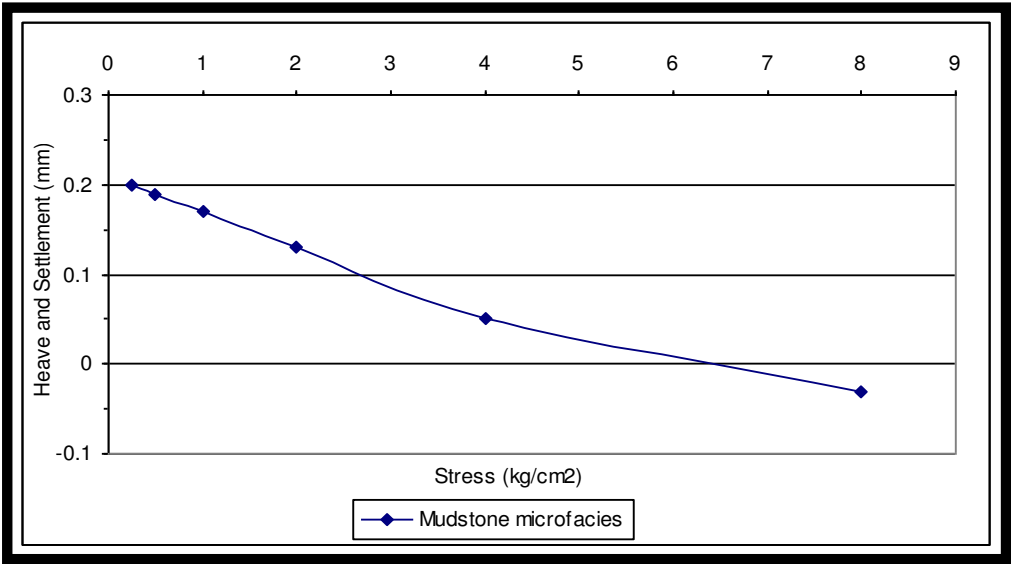

Fig.8. Vertical deformation (Heave and Settlement) versus stress levels for mudstone microfiches

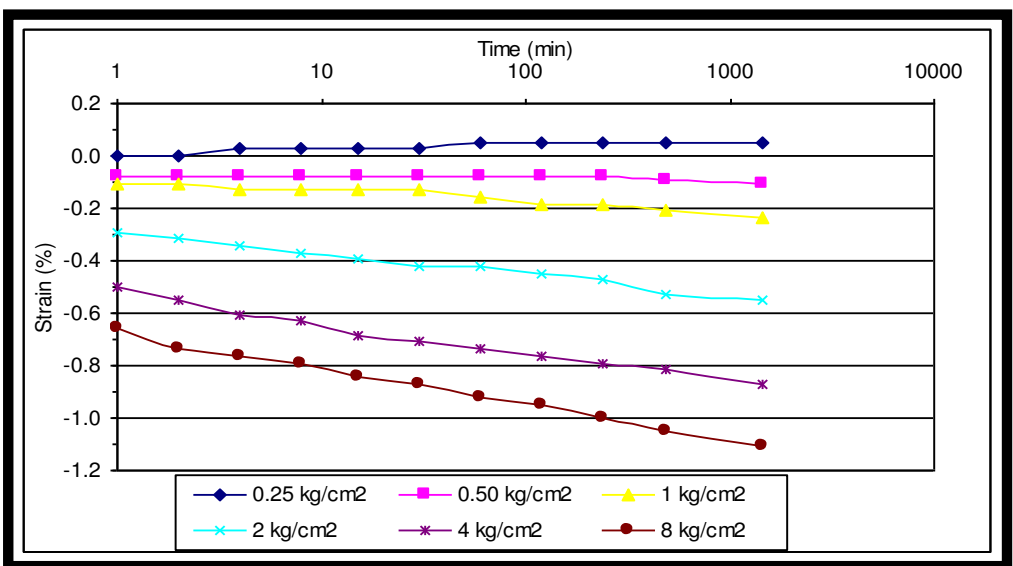

Fig. 9.Vertical deformation versus time under different applied stress levels for treated crushed mudstone microfiches for 7 days

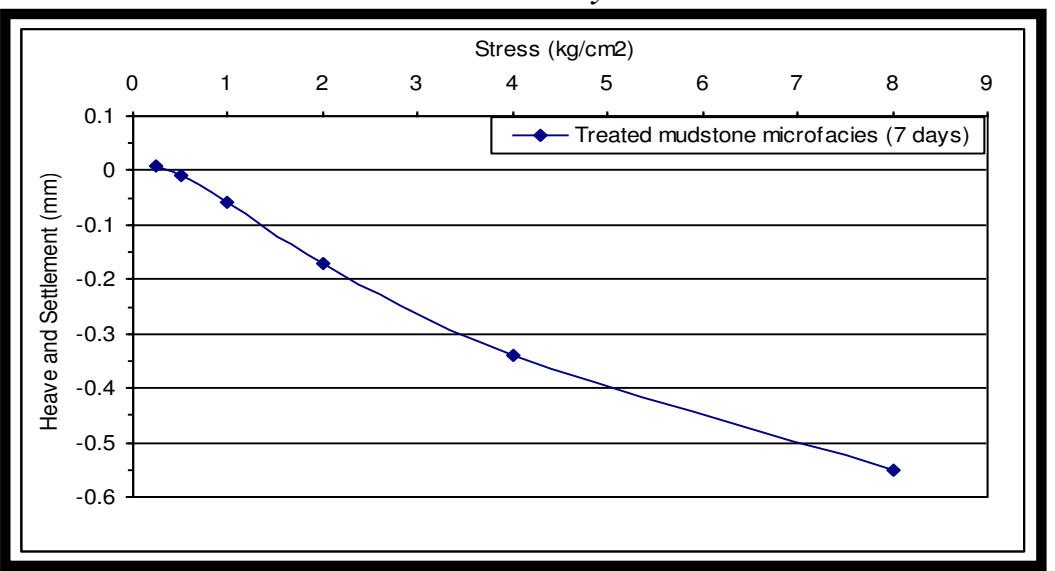

Fig.10.Vertical deformation(Heave and Settlement) versus stress levels for treated crushed mudstone microfacies for 7 days

Journal of Engineering Sciences, Assiut University, Faculty of Engineering, Vol. 41, No. 5, September, 2013, E-mail address: jes@aun.edu.eg 
Fig. (11) shows the relation between the vertical displacements versus time for the lime treated mudstone cured for 28days. The figure indicates that the previous relation is obtained under six stress levels $\left(0.25,0.50,1,2,4\right.$ and $\left.8 \mathrm{~kg} / \mathrm{cm}^{2}\right)$. It could be noticed that the zero time started from the moment of adding water to the loaded treated mudstone sample. The figure illustrates that there is no any heave of the studied sample. The studied sample is compressed (settlement) with increase of stresses values $(0.25,0.50,1,2,4$ and $8 \mathrm{~kg} / \mathrm{cm}^{2}$ ) to $1.79 \%$. The rate of settlement increased by increase of time and stress levels. The difference of settlement values and their increase rate under effect of the stresses $\left(0.25,0.50\right.$ and $\left.1 \mathrm{~kg} / \mathrm{cm}^{2}\right)$ are relatively small but The difference between $\left(1\right.$ and $\left.2 \mathrm{~kg} / \mathrm{cm}^{2}\right)$ are relatively large and the difference between $\left(2,4\right.$ and $\left.8 \mathrm{~kg} / \mathrm{cm}^{2}\right)$ are relatively small.

Fig. (12) shows the change of the vertical displacement of lime treated mudstone sample cured for 28 days with stress levels recorded at the end of tested period of 24 hours. It could be noticed from this figure that there is no any heave happened under the effect of stresses. The settlement of the studied sample happened under effect of stresses equal to $0.25,0.50,1,2,4$ and $8 \mathrm{~kg} / \mathrm{cm}^{2}$. The figure explained that the swelling pressure of this sample is $0.25 \mathrm{~kg} / \mathrm{cm}^{2}$.

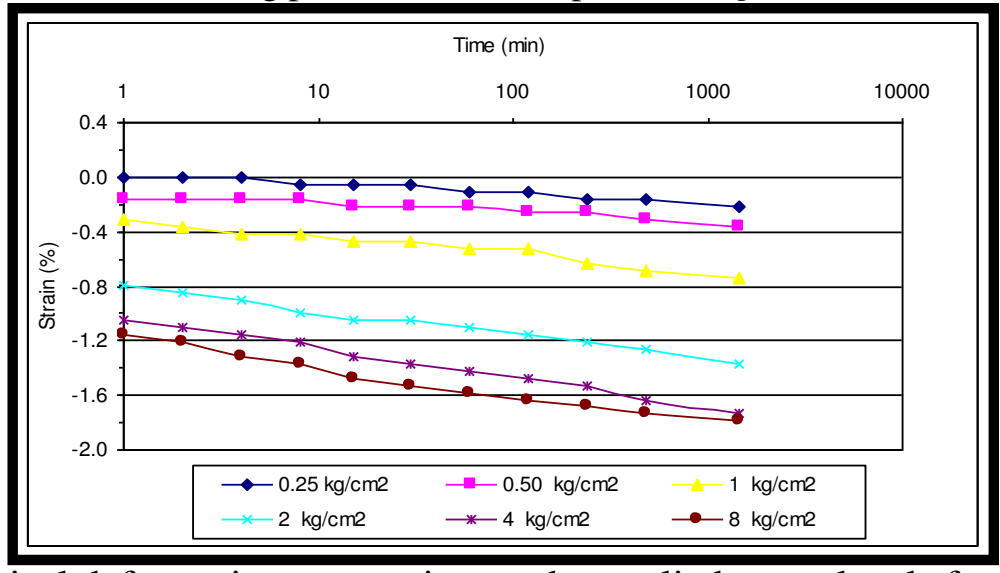

Fig. 11.Vertical deformation versus time under applied stress levels for treated crushed mudstone microfacies for 28 days

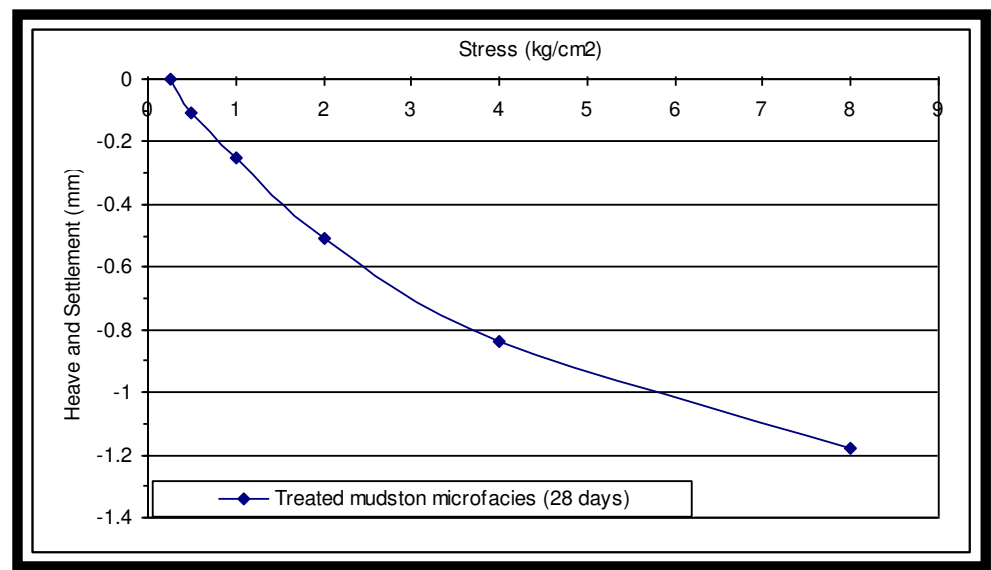

Fig.12.Vertical deformation (Heave and different Settlement) versus stress levels for treated crushed mudstone microfacies for 28 days

Journal of Engineering Sciences, Assiut University, Faculty of Engineering, Vol. 41, No. 5, September, 2013, E-mail address: jes@aun.edu.eg 
Afaf A H M.et al., Treatment of Expansive Subgrade By Lime Addition, pp. 1778 - 1795

Effect of lime stabilization and curing period on swelling potential of natural soil is shown in Fig.(13). The swelling potential for natural, and treated soil for 7 and 28 days were 650 , 40 , and $0 \mathrm{kpa}$ respectively. Adding lime to soil decrease the swelling potential for natural soil to about $1 / 6$ of its initial value. However, the curing for at 28 days almost make the treated sample with no swelling.

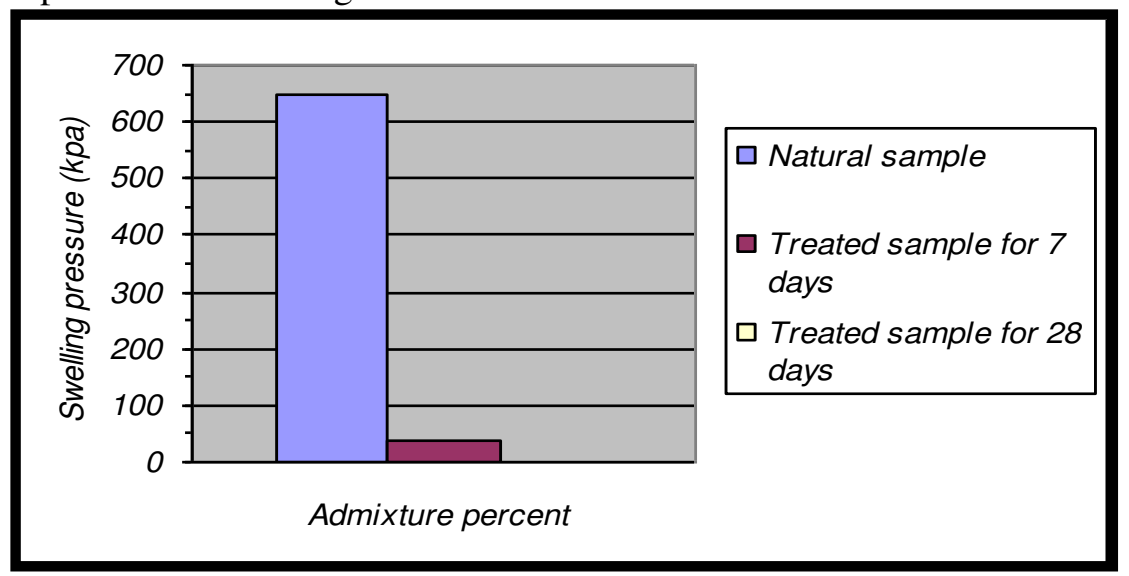

Fig. 13. Effect of lime addition ancuring period on swelling pressure

\subsection{Unconfined compressive strength test results}

Unconfined compressive strength of both untreated compacted and lime treated mudstone is measured according to DIN 18 136. Mudstone-lime mixtures was prepared at the optimum lime content $(6 \%)$ and compacted at optimum water content and cured for 7 and 28 days.

Fig (14) illustrates stress-strain curves of both untreated compacted and lime treated mudstone (7 and 28days curing). The results showed that, unconfined compressive strength values are increased using lime treatment from 5.96 to $33.45 \mathrm{~kg} / \mathrm{cm}^{2}$ at curing time 7 days. With increase of curing time from to 28 days, the values increased to $39.65 \mathrm{~kg} / \mathrm{cm}^{2}$. Strength gain due to lime addition and after 7 days curing is 5.61 . With increasing of curing time from 7 to 28 days, the strength gain is increased from 5.61 to 6.65 .

Effect of lime stabilization and curing period on unconfined compressive strength on untreated soil is shown in Fig.(15). Unconfined compressive strength for untreated and treated soil for7 and 28 days were 5.96, 33.45, and $39.65 \mathrm{~kg} / \mathrm{sq} . \mathrm{cm}$ respectively. Adding lime to soil increase the unconfined compressive strength for untreated soil by about seven and eight times at 7 days and at 28 days curing of its initial value.

Journal of Engineering Sciences, Assiut University, Faculty of Engineering, Vol. 41, No. 5, September, 2013, E-mail address: jes@aun.edu.eg 


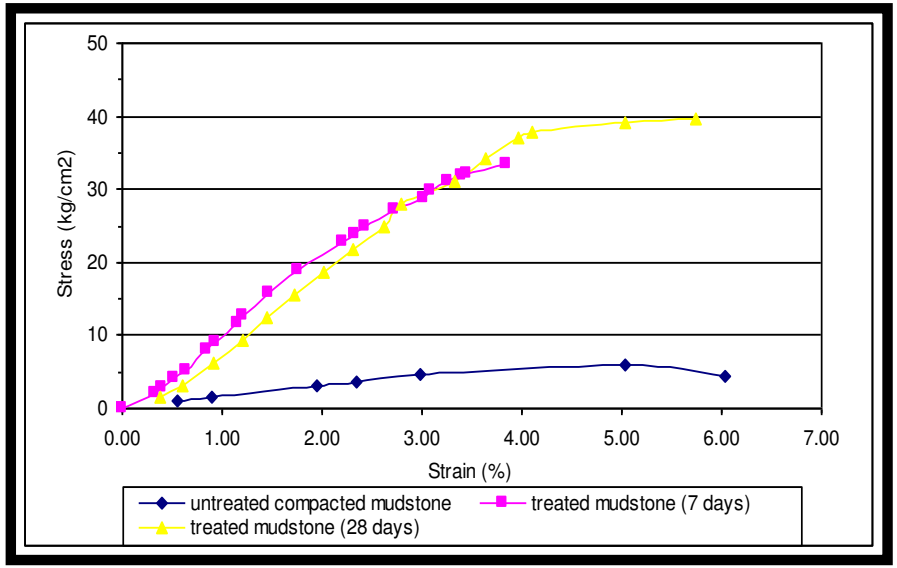

Fig.14. Unconfined compressive strength of and curring period on untreated and treated stabilized mudstone strength samples for $7 \& 28$ days

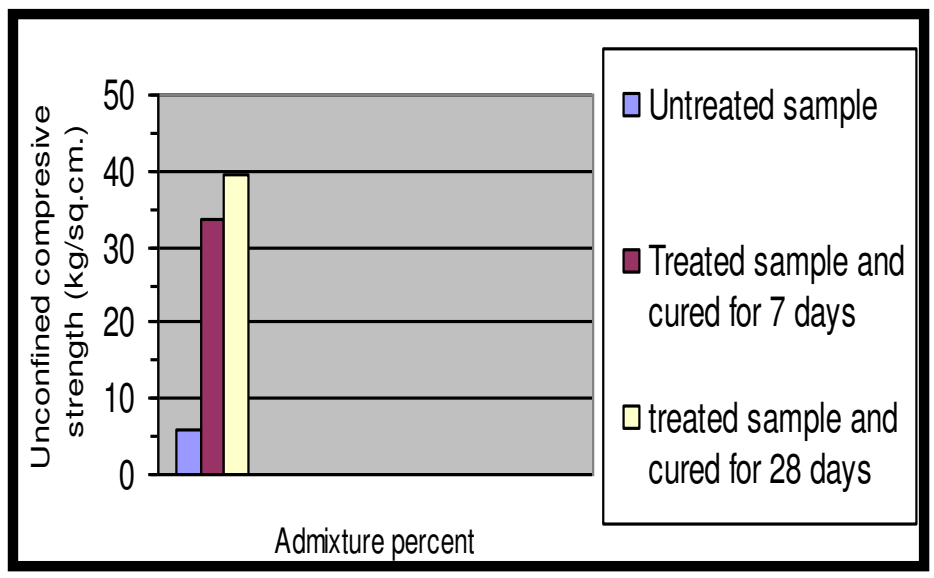

Fig. 15. Effect of lime addition and curring period on unconfined compressive strength

\subsection{California bearing ratio (CBR) test results}

CBR-value is used as an index of bearing capacity. This value is broadly used and applied in design of the base and the sub-base material for pavement. Lime-stabilized soils are often used for constructing of the pavement layers and also for an embankment (Ismaiel, 2006). CBR-test was conducted to characterize the bearing capacity of the studied untreated compacted and lime treated mudstone.

$C B R$-values is measured after 7 and 28days curing. The results showed that the lime addition leads to increase $C B R$-values of the studied samples from 12.21 to $100 \%$ at curing time 7 days. With increase of curing time to 28 days, $C B R$-values increased to $122.9 \%$, Fig. (16). $C B R$-gain due to lime addition after 7 days curing time is 8.19. and 10.07 after 28days.

Journal of Engineering Sciences, Assiut University, Faculty of Engineering, Vol. 41, No. 5, September, 2013, E-mail address: jes@aun.edu.eg 


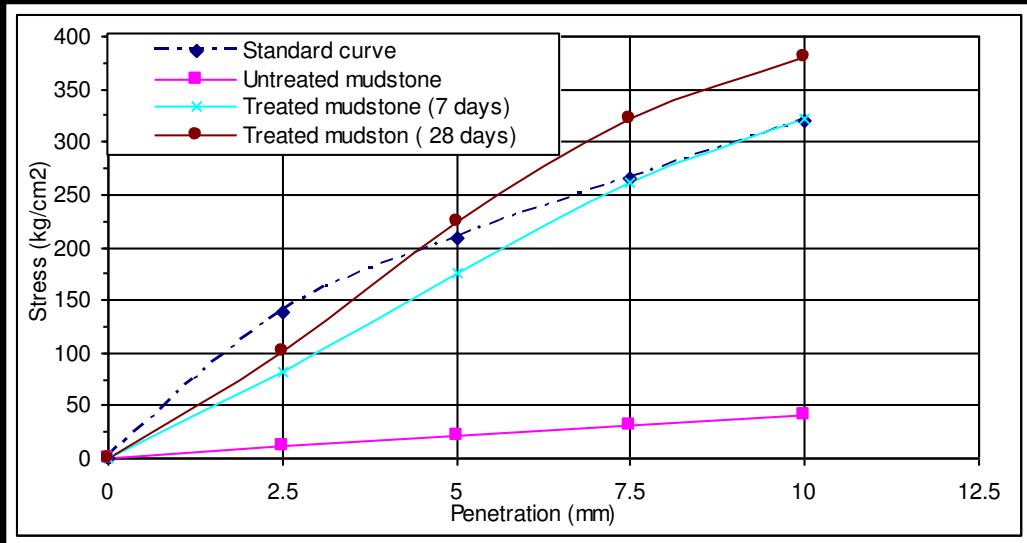

Fig. 16. CBR-curves of both untreated and treated mudstone.

\subsection{Durability test results}

The lime mudstone mixtures (6\% lime, cured for 7 and 28days) were subjected to wetting/drying test according to ASTM D559 including 12cycles of wetting/drying. The procedures of the test are similar to the procedures of the standards test method for compacted cement mixtures except wire brushing after each cycle is omitted (U.S. Army, Air force and Navy, 2005). The test consists of twelve two-day cycles of wetting/drying, which means that the test requires 24 days to complete. Treated mudstone mixtures, that satisfy strength requirements, are required to pass these tests to prove their ability to withstand environmental condition (Baghdadi et al., 1995). The results of the durability test were expressed in terms of weight loss at the end of the 12 cycles.

The weight loss criteria and the durability test results of the treated mudstone after 12cycles are shown in Tables [5] and [6]. The treated lime mudstone samples cured for 7 days failed, in contrast the samples cured for 28 days passed.

\section{Table 5.}

Durability test results.

\begin{tabular}{|c|c|c|c|}
\hline Specimens & $\begin{array}{c}\text { Number of } \\
\text { specimens }\end{array}$ & $\begin{array}{c}\text { Durability test results } \\
\text { Wet/Dry (ASTM D559) }\end{array}$ & $\begin{array}{c}\text { Weight } \\
\text { loss (\%) }\end{array}$ \\
\hline $\begin{array}{c}\text { Crushed mudstone+6\% lime } \\
\text { (7days) }\end{array}$ & 2 & fail & 15 \\
\hline $\begin{array}{c}\text { Crushed mudstone+6\% lime } \\
(28 \text { days })\end{array}$ & 2 & pass & 1 \\
\hline
\end{tabular}

Journal of Engineering Sciences, Assiut University, Faculty of Engineering, Vol. 41, No. 5, September, 2013, E-mail address: jes@aun.edu.eg 


\section{Table 6.}

Durability test weight loss criteria (durability requirements) according to (ASTM D559).

\begin{tabular}{|c|c|}
\hline Type of treated particles & $\begin{array}{c}\text { Maximum allowable weight loss after 12 wet-dry } \\
\text { cycles percent of initial specimen weight }\end{array}$ \\
\hline Granular, PI $<\mathbf{1 0}$ & 11 \\
\hline Granular, PI $>\mathbf{1 0}$ & 8 \\
\hline Silt & 8 \\
\hline Clay & 6 \\
\hline
\end{tabular}

\subsection{SEM-analysis (microstructural analysis)}

The changes of microstructural and microstructural development of soils due to lime addition play significant role in the geotechnical properties and the mechanical behaviour of these stabilized soils. The changes of the microstructural of the tested soil due to lime addition was investigated using JEOL-JSM-6300 scanning electron microscope operated at $20 \mathrm{KV}$. Undisturbed cubical specimen $\left(10 \mathrm{~mm}^{*} 10 \mathrm{~mm}\right)$ of both the natural and the stabilized soil was prepared and dried in the oven at $40^{\circ} \mathrm{C}$ and subsequently subjected to datum. The tested specimen was glued on aluminum holders for scanning. The fractured surface of the specimen was coated with gold instead of carbon to get images with a good quality.

Fig. (16, a) shows the ESM-micrograph of natural mudstone which illustrates the sheetlike structure. Fig. $(16, b)$ shows crumbs of floccules with a porous nature and cementitous compounds (calcium aluminum hydrate and calcium silicate hydrate) coating the relics of the clay particles and the plocs the lime treated mudstone curred for 7days. The edges of the relics of the clay particles were attacked by lime and their boundaries have a raggedform. The reaction of lime with clay leads to the formation of aggregates of various sizes and this is responsible for the increase in porosity. Similarly microfabric was observed by Rajasekaran et al., 1998, Ismaiel, 2006 and others.

Fig. $(16, \mathrm{c})$ shows the micrograph of the treated mudstone (6\% lime) cured for 28 days. The micrograph illustrates the aggregated arrangements due to flocculation and a new formation of hydration reaction products coating and cementing the particles, that leads to reduce the porosity of the particles system.

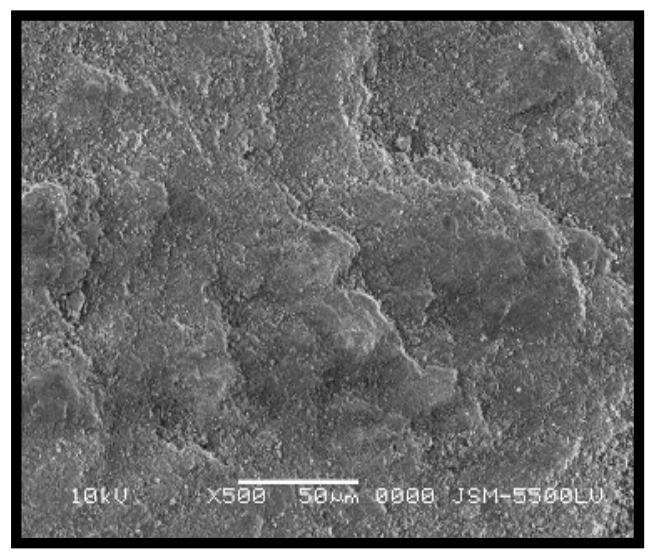

Fig.16. a. Scanning electron micrograph of natural mudstone

Journal of Engineering Sciences, Assiut University, Faculty of Engineering, Vol. 41, No. 5, September, 2013, E-mail address: jes@aun.edu.eg 


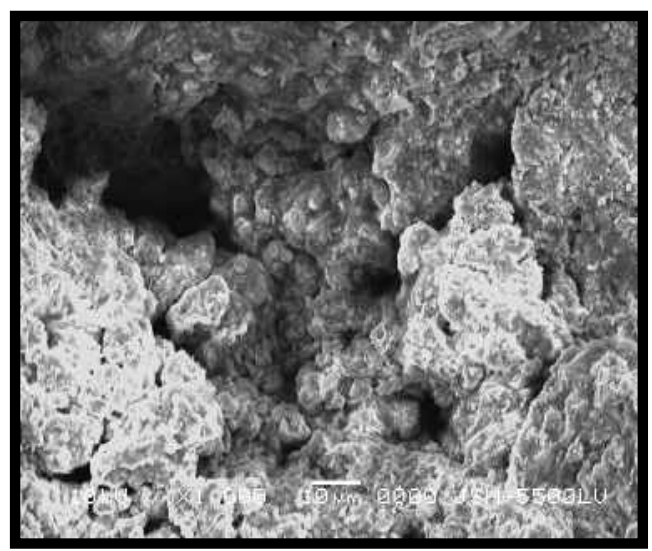

Fig. 16. b. Scanning electron micrograph of lime treated mudstone (6\% lime) cured for 7 days

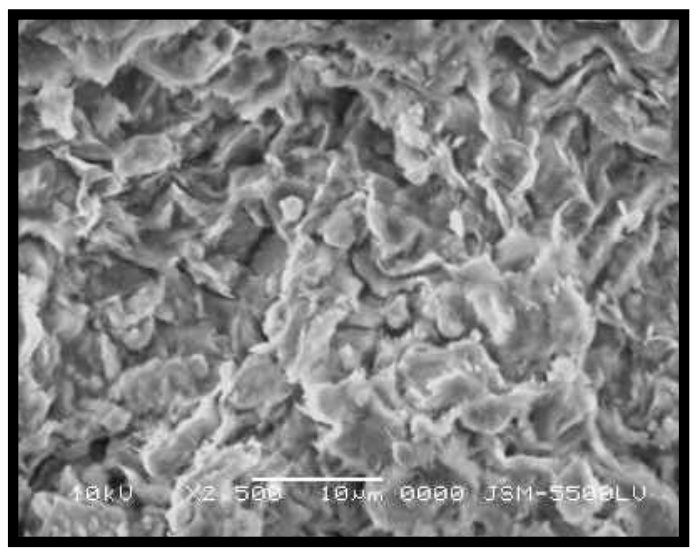

Fig. 16. c. Scanning electron micrograph of lime treated mudstone (6\% lime) cured for 28days

\section{Conclusions}

The aim of the treatment is stabilizing the Mudstone microfacies and improving its geotechnical properties. Chemical soils stabilization program using hydrated lime was applied to improve and treat the swelling and the other geotechnical properties such as plasticity, compaction, unconfined compressive strength, California bearing ratio, and durability of mudstone microfacieses. The optimum lime content (according to $\mathrm{pH}$ method) of an expansive soil is taken $6 \%$ in the percent investigation.

The main conclusion which can be obtained from the present investigation are :(1)The hydrated lime added to crushed mudstone microfacies led to reduce the plasticity index, where the plasticity index reduced from $9.95 \%$ to $4.36 \%$.

(2) The addition of lime to the crushed mudstone microfacies leads to an increase in the optimum moisture content and a decrease in the maximum dry density, where the optimum

Journal of Engineering Sciences, Assiut University, Faculty of Engineering, Vol. 41, No. 5, September, 2013, E-mail address: jes@aun.edu.eg 
moisture content increased from 18.6 to $19.4 \%$, in contrast dry density decreased from 1.67 to $1.62 \mathrm{~g} / \mathrm{cm}^{3}$.

(3)The moisture-density curves of the stabilized soils have a typical flattened form. This typical flattening of the compaction curves makes it easier to achieve the required density over a wider range of possible moisture contents.

(4)The addition of lime to the crushed mudstone microfacies leads to decrease the swelling potential for natural soil to about $1 / 6$ of its initial value. However, the curing for at 28 days almost make the treated sample with no swelling.

(5)The addition of lime to the crushed mudstone microfacies leads to an increase in unconfined compressive strength from 5.96 to $39.65 \mathrm{~kg} / \mathrm{cm}^{2}$.

(6)The addition of lime to the crushed mudstone microfacies leads to an increase in California bearing ratio $(C B R)$ from 12.21 to $122.9 \%$.

(7)Scanning electron microscope studies of the stabilized soil indicated that the microstructures of the tested mudstone microfacies changed due to lime-addition. The $S E M$-micrographs of natural and treated stabilized soils indicated the formation of new cementitous compounds and mineral crystals as a pozzolanic reaction product through the long-term curing.

\section{References}

[1] AASHTO, T 90 (2010): Standard Method of Test for Determining the Plastic Limit and Plasticity Index of Soils, Single User Digital Publication American Association of State Highway and Transportation Officials, 20 th edition, Washington, DC.

[2] Anon (1985): Lime Stabilization Manual. Eighth Edition, National Lime Association, Arlington, Va.

[3] Anon (1990): Lime Stabilization Manual. British Aggregate Construction Materials Industry, London.

[4] Baghdadi Z.A., Fatani M.N. and Sabban N.A. (1995): Soil modification by cement kiln dust. Journal of Materials in Civil Engineering, Vol. 7, No. 4, pp: 218-222.

[5] Bowles J. (1992): Engineering properties of soil and their measurements. McGraw-Hill Boston, $4^{\text {th }}$ edition.

[6] -Casagrand,A. (1932): Research on the Atterberg limits of soils. Public Roads, (13):121136.

[7] FGSV: TPBF-StB, teil B 7.1 (1988): CBR-Versuch, Technische Pruefvorschriften.

[8] Chen, F.H. (1975): Foundation on expansive soils, Elsevier Science, Amsterdam.

[9] Nelson, J.D., and Miller, D.J.(1992): Expansive soils. Problems and practice in foundation and pavement engineering, Wiley, New York.

[10] Compendium-8 (1979): State of the art, lime stabilization, transportation research circular, transportation research Bd., Natl. research concil, Washington. D.C., pp: 45-75.

[11] Egyptian Code (2001): Egyptian Code of Soil Mechanics, Foundations Carrying out and Designation. Part 2, Laboratory Tests, Six Edition, 314p.

[12] Erdal and Cokça (2001): Use of class C fly ashes for the stabilization of an expansive soil, Journal of geotechnical and geoenvironmental engineering.

[13] Ismaiel H.A.H (2006): Treatment and improvement of the geotechnical properties of different soft fine-grained soils using chemical stabilization. Doctoral work thesis, Mathematisch-Naturwissenschaftlich-Technischen Fakultat, Martin-Luther Universitat Halle-Wittenbeerg, Germany, Shaker Verlag, ISBN-10:3-8322-5508-7.

[14] Ito M. and Azam S. (2010): Determination of swelling and shrinkage properties of undisturbed expansive soils. Geotech Geol Eng, Vol. 28, pp: 413-422.

Journal of Engineering Sciences, Assiut University, Faculty of Engineering, Vol. 41, No. 5, September, 2013, E-mail address: jes@aun.edu.eg 
Afaf A H M.et al., Treatment of Expansive Subgrade By Lime Addition, pp. 1778 - 1795

[15] Kehew, A. E.(1995): Geology for engineers and environmental scientists. Prentice-Hall, Englewood Cliffs, N.J.

[16]-Laguros J.G, .Davidson D.T., Handy R. L. and Chu T. Y. (1956): Evaluation of lime for stabilization of loess, Proc. of Amer. Soc. for testing and materials, Vol. (56) pp: 1301-1319.

[17] Mahrous A.M., Tantawi M.M. and El-Sageer H. (2010): Evaluation of the engineering properties of some Egyptian limestones as construction materials for highway pavements. Construction and Building Materials journal, Vol. 24, pp: 2598-2603.

[18] Okonta F.N. and Manciya T. M. (2010): Compaction and strength of lime - fly Ash stabilized collapsible residual sand. EJGE, Vol.15, Bond, R.

[19] Ramadan E.H. (1996): In situ chemical stabilization of expansive clay soil by lime additive. $7^{\text {th }}$ international colloquium on structural and geotechnical Eng. Ain Shams univ. Cairo, Egypt. pp:403-419.

[20] Rajsekaran G. and Narasimha Rao S. (1998): Particle size analysis of lime-treated marine clays. Geotechnical Testing Journal, Vol. (21) no. 2, pp: 109-119.

[21] Tensar Technical Note, TTN (1998): Chemical and mechanical stabilization of subgrades and flexible pavement sections. TTN, BR 10, July 1998.

[22] Transportation Research Board (TRB). (1976): "State of the art: Lime stabilization reactions, properties, design, construction."Transp. Res. Circular No. 180, Wasington, D.C

[23]-TRB (1987): Lime stabilization: Reaction, Properties, Design, and Construction. State of Art Report 5, Transportation Research Board, National Research Council, Washington, DC.

[24] U.S. Army, U.S. Navy and U.S. Air Force (2005): Soil stabilization for pavements, University press of the pacific, Honolulu, Hawaii.

[25] Zhang J.R. \& Cao X.(2002):Stabilization of expansive soil by lime and fly ash. Journal of Wuhan University of Technology, Materials Science Edition, Vol. 17, No. 4, pp73-77.

Journal of Engineering Sciences, Assiut University, Faculty of Engineering, Vol. 41, No. 5, September, 2013, E-mail address: jes@aun.edu.eg 
طريق قناـ سفاجا ذو أهمية قصوي في ربط محافظات الوجة القبلي بمحافظة البحر الاحمر ولقد تم الاتجاه في

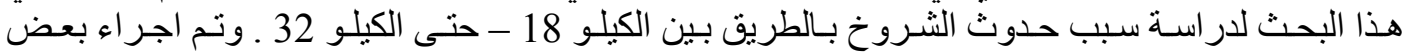

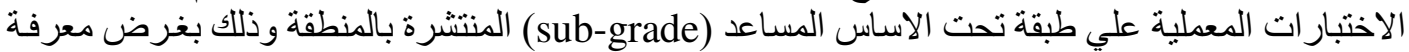

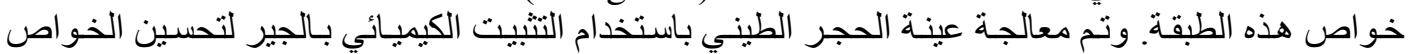

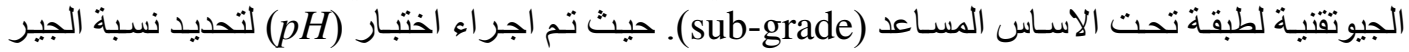

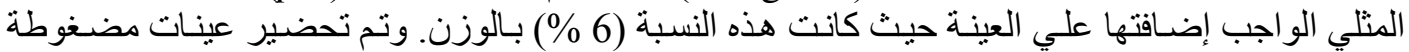

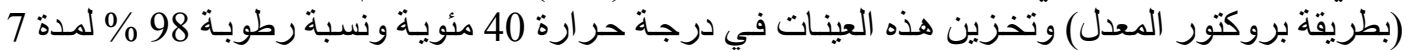

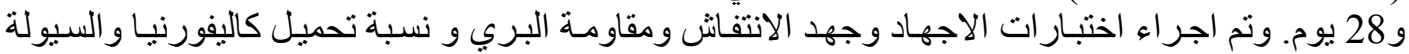

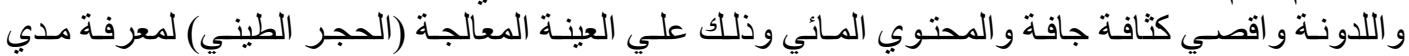
التحسن في هذه الخواص بعد اضافة الجير .وكانت النتائج كآلاتي:-

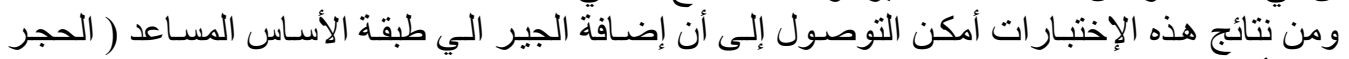

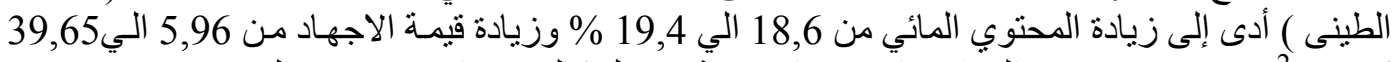

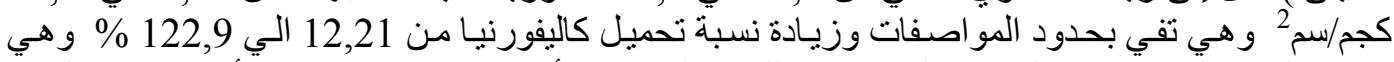

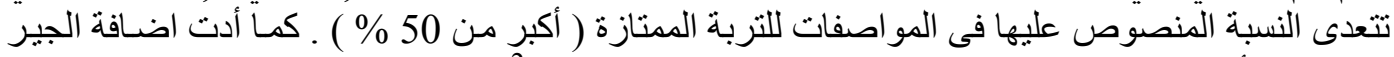

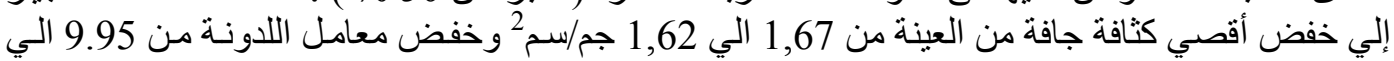

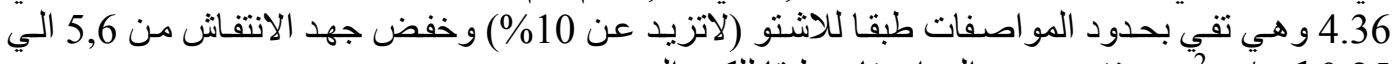

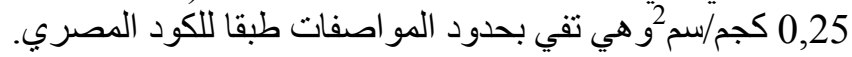

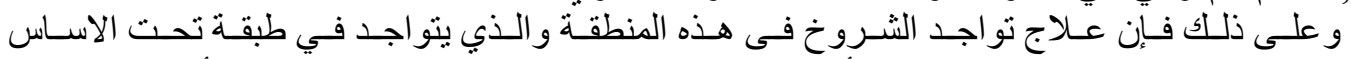

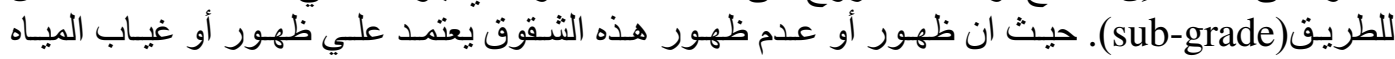

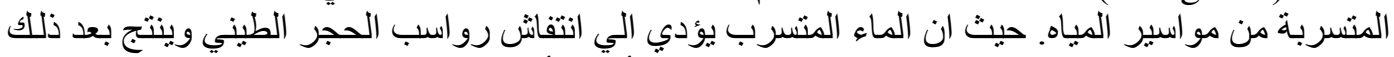

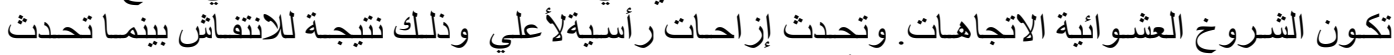

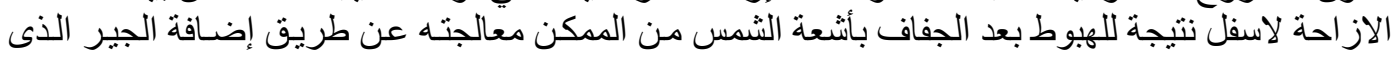

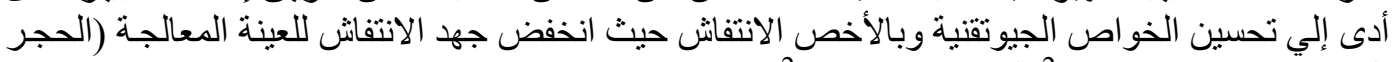

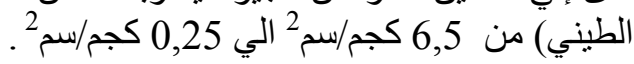

Journal of Engineering Sciences, Assiut University, Faculty of Engineering, Vol. 41, No. 5, September, 2013,E-mail address: jes@aun.edu.eg 